JURNAL AL BAYAN: JURNAL JURUSAN PENDIDIKAN BAHASA ARAB

p-ISSN 2086-9282 | e-ISSN 2549-1229

\title{
The Effectiveness of Fun Learning Approach in Arabic Learning
}

\author{
Betty Mauli Rosa Bustam $^{1 *}$, Iswanto ${ }^{2}$, Mhd. Lailan Arqam³ ${ }^{3}$, Wikanti Iffah Juliani ${ }^{4}$, \\ Akhmad Najibul Khairi ${ }^{5}$ \\ ${ }^{1}$ Magister of Islamic Education Universitas Ahmad Dahlan Yogyakarta, Indonesia \\ ${ }^{2}$ Muhammadiyah Elementary School of Kadisoka Yogyakarta, Indonesia \\ ${ }^{3}$ Magister of Islamic Education Universitas Ahmad Dahlan Yogyakarta, Indonesia \\ ${ }^{4}$ Muhammadiyah Junior High School of Prambanan 1 Yogyakarta, Indonesia \\ ${ }^{5}$ Social Science Western Sydney University, Australia
}

\author{
Article History: \\ Received : April 03, 2021 \\ Revised : May 05, 2021 \\ Accepted : June 04, 2021 \\ Published : December 01, 2021
}

Keywords:

Arabic Teaching; Fun learning; Text Book; Vocabulary

*Correspondence Address: betty.rosa@bsa.uad.ac.id

\begin{abstract}
Learning Arabic is often a burden for students, not only because the difficulty of its materials, but also the methods used by the teachers are often not attractive to students. This study aimed to develop Arabic learning materials for first grade in elementary school that will be based on fun learning approach. The method used in this research was Classic Experimental Design by dividing two classes in which one of the classes was utilized as a control class, and others were as experimental class (both 29 students), which would receive an experiment from the development of previous learning materials. The research result showed that the experimental class obtained an average difference score was about 27,2 with the highest score was 100 , while the control class was about 10,3 with the highest score was 80 . This study showed that there was a significant improvement in the test results of students in the experimental class, these results indicate that the use of textbook based on the song was more effective for students in Arabic learning. According to the results of this study and several other studies related to learning methods for the first graders in elementary school, this article provides an alternative learning method for Arabic teachers which has proven its effectiveness in delivering material. It is hoped that teachers can innovate to replace learning methods with fun learning which is more attractive to students.
\end{abstract}

\section{Introduction}

Islamic teachings contained in the Holy Qur'an and Hadith used Arabic as an introductory language. Furthermore, Arabic become a prominent key to understand the Islamic religion well. The people need to study in-depth to understand what is contained in Holy Qur'an, Hadith, and all of the teachings used Arabic as a primary language. Arabic holds a special place and importance as a language that is used in any religious 
activities $^{1,2}$. It is a language that includes 30 modern varieties. There are millions of people speaking Arabic all around the world. Arabic has a big role to play as a holy language of Al-Quran ${ }^{3}$. Since the arrival of Islam in Indonesia, Arabic was known as a language of religion. Arabic has an essential role in the development of a religious character. Arabic is also one of the corpus of classical civilization and the oldest foreign language. Arabic also has a huge role in the educational process and the development of the religious attitude of the learners as well as society in general ${ }^{4}$. There was a symbioticmutualism relationship between Islam and Arabic, between religion and language, or between doctrine and media of communication so that both develop support each other.

Since it was first introduced in 2010, Arabic learning in the first grade of Muhammadiyah Kadisoka Elementary School had been held formally following the curriculum. Arabic learning in Muhammadiyah school is aimed to learn Islamic religion deeply and comprehesively. The approaches used to deliver the lessons tend to be formal and sacral, as well as taught together with the introduction of Al-Qur'an letters (hijaiyah). Due to the lack of learning facilities and infrastructure, the learning activity only relies on textbooks which is provided by the school. Students look bored because of the lack of reference to the subject matter and are not enthusiastic in the teaching and learning process carried out by the teacher. Consequently, the students of first grade that are still classified as children encounter the difficulties and also lost interest in learning Arabic. According to Cahaya ${ }^{5}$ she stated that students' lack of interest in learning was caused by the monotonous method which only stuck on memorizing, questioning and answering, exercising, doing so much homework, and writing. Arabic is one of the compulsory subjects that determine the graduation of students in the school. Different

\footnotetext{
1 Ismail Suardi Wekke, "Arabic Teaching and Learning: A Model From Indonesian Muslim Minority," Procedia-Social and Behavioral Sciences 191. (2015): 286-90.

${ }^{2}$ Sami Boudelaa and William D. Marslen-Wilson, "Morphological Structure in the Arabic Mental Lexicon: Parallels between Standard and Dialectal Arabic," Language and Cognitive Processes 28, no. 10 (December 2013): 1453-73, https://doi.org/10.1080/01690965.2012.719629.

${ }^{3}$ Mohammad H. Al-Khresheh, Ahmad Khaerurrozikin, and Abdul Hafidz Zaid, "The Efficiency of Using Pictures in Teaching Speaking Skills of Non-Native Arabic Beginner Students," Universal Journal of Educational Research 8, no. 3 (2020): 872-78, https://doi.org/10.13189/ujer.2020.080318.

4 Agus Arwani, "The Role of The Arabic Language in Islamic Economy," Alsinatuna 3, no. 1 (2013): 97-112.

5 Meta Cahaya, "Penerapan Model Pembelajaran Inkuiri Untuk Meningkatkan Motivasi Belajar PPKn Siswa Di Kelas VII C SMP Negeri 7 Muaro Jambi,” Thesis, July 23, (2020): 2.
} 
Arabic language teaching and learning programs, textbooks and teaching techniques are used by various institutions in Arabic as well as foreign institutions ${ }^{6}$.

Arabic subject which is taught in the first grade of Muhammadiyah Kadisoka Elementary School contains the understanding and memorizing the basic vocabularies. It is aimed for the students to know the Arabic vocabulary (in Arabic usually called Mufradhat) and to arrange the sentences. Language users rely more on vocabulary than grammar when they communicate as Wilkins (1972) argued, "Without grammar, little words can be said; without vocabulary, there's nothing to say"7. The concept of vocabulary knowledge is not one-dimensional and this concept must be clearly defined, especially if it's referenced in a vocabulary test $^{8}$. However, the textbook used for teacher's guideline is only an Arabic-English thematic dictionary that contains pictures and the meanings followed by specific themes. Therefore, the approaches used by the teachers and uninteresting textbooks become essential causes of the unfulfilled target of an Arabic language learning in the first grade of Muhammadiyah Kadisoka Elementary School. Language teachers are expected to teach the student besides other content, without any clear justification for their role in improving the learners' language and how closely it relates to other systematic language skills ${ }^{9}$.

There have been several previous studies about learning foreign language methods for children: (1) Susilawati's ${ }^{10}$ study on the application of the singing method to improve language skill in early childhood education stated that learning by song or singing can improve children's skills in communication and interaction. (2) Markus Christiner and Susanne Maria Reiterer's research about the use of song related to

${ }^{6}$ Reima S. Al-Jarf and Nailya G. Mingazova, "Evaluation of Arabic Language Teaching Textbooks Used in Russia in the Light of the CEFR Criteria," in VI International Forum on Teacher Education, vol. 1, (2020): 101-29, https://doi.org/10.3897/ap.2.e0101.

${ }^{7}$ Satit Somjai and Kittitouch Soontornwipast, "The Integration of Implicit and Explicit Vocabulary Instruction, Project-Based Learning, Multimedia, and Experiental Learning to Improve Thai EFL Senior High School Students' Vocabulary Ability," Arab World English Journal 6, no. Special (2020): 171-90, https://doi.org/https://dx.doi.org/10.24093/awej/call6.12.

8 Ahmed Masrai and James Milton, "Recognition Vocabulary Knowledge and Intelligence as Predictors of Academic Achievement in EFL Context.," TESOL International Journal 12, no. 1 (2017): $128-42$.

${ }^{9}$ Ali H. Al-Bulushi and Ali S. Al-Issa, "Playing with the Language: Investigating the Role of Communicative Games in an Arab Language Teaching System," International Journal of Instruction 10, no. 2 (2017): 179-98, https://doi.org/10.12973/iji.2017.10212a.

10 Susilawati Susilawati, "Penerapan Metoda Bernyanyi Dalam Memingkatkan Kecerdasan Berbahasa Pada Pendidikan Anak Usia Dini (Studi Deskriptif Tentang Penerapan Metoda Bernyanyi Di PAUD Al Azhar Syfa Budi Parahyangan)," EMPOWERMENT : Jurnal Ilmiah Program Studi Pendidikan Luar Sekolah, vol. 3, September 30, (2014), https://doi.org/10.22460/EMPOWERMENT.V3I2P141151.581 . 
children's phonetic language skills starting around the age of 5, they suggest that music and language learning capacity (foreign) can be linked since childhood. Their study emphasize the possibility that children's early developed abilities may be responsible for the difference's individuals in linguistic and musical performance ${ }^{11}$. (3) Davis ${ }^{12}$ research stated that the songs have been a common feature of young learner in the classrooms for decades and should be employed in order to improve motivation and facilitate the acquisition of various aspects of language, including vocabulary, grammar, pronunciation, and listening skills. (4) Erisa Kurniati's research about audio media for English learning based on scripted song at the $5^{\text {th }}$ grade of elementary school, proves that the use of songs in foreign languages learning for elementary school students is very significant $^{13}$. (5) Nihada Delibegović Džanić and Alisa Pejić's study on the effect of using songs on young learners and their motivation for learning English showed that there are so many aspects of a language that can be delivered and recycled through the use of songs. They can be used at any stage of a lesson and there are many ways to encourage them into a lesson ${ }^{14}$.

The five studies that have been conducted above have indeed strengthened the researchers' assumption in the foundation of using song in Arabic learning. The difference between this research and the previous ones is that it is aimed at the $1^{\text {st }}$ grade curriculum of Muhammadiyah elementary school which has a special purpose in learning Arabic and is studied as one of the compulsory subject that will affect student graduation later. The study used in this research replaces the previous approach used by Arabic teachers in grade 1 of Muhammadiyah elementary school of Kadisoka by a fun learning approach. Referred to this study, Fun Learning is a holistic approach to education to nurture the passion for learning and continuous development throughout life ${ }^{15}$. Fun

11 Markus Christiner and Susanne Maria Reiterer, "Early Influence of Musical Abilities and Working Memory on Speech Imitation Abilities: Study with Pre-School Children," Brain Sciences 8, no. 9 (2018), https://doi.org/10.3390/brainsci8090169.

${ }^{12}$ G Davis, "Songs in the Young Learner Classroom: A Critical Review of Evidence," ELT Journal 71, no. 4 (2017): 445-55, https://doi.org/10.1093/elt/ccw097.

${ }^{13}$ Erisa Kurniati et al., "The Effectiveness of Audio Media for English Learning Based on Scripted Song at the Fifth Grade of Elementary School," Ilkögretim Online 20, no. 1 (2021): 208-16, https://doi.org/10.17051/ilkonline.2021.01.023.

${ }^{14}$ Nihada Delibegović Džanić and Alisa Pejić, "The Effect of Using Songs On Young Learners and Their Motivation for Learning English," NETSOL: New Trends in Social and Liberal Sciences 1, no. 2 (2016): 40-54, https://doi.org/10.24819/netsol2016.8.

15 "Fun Learning Approach - Nurturing A Passion For Learning • Fun Academy," accessed September 21, 2020, https://funacademy.fi/fun-learning-approach/. 
Learning approach encourages collaborative learning through play and exploration. One of the ways used to fulfill the element of fun learning is by creating a textbook based on the songs. Referred to Pasiak ${ }^{16}$, musical art, especially songs, is high nutrition for the brain. According to Susilawati ${ }^{17}$, in the educational neuroscience, art can make brain development staying balanced and will make the learning atmosphere fun and exciting. Multidimensional contains the understanding that art is a medium for the development of various competencies of learners, including knowledge, understanding, analysis, evaluation, appreciation, expression, and creation by harmoniously integrating elements of aesthetics, logic, and ethics ${ }^{18}$.

Bobbi DePorter stated that a fun learning strategy is a strategy used to create an effective learning environment, apply the curriculum, deliver the material, ease the learning process that make the improvement of students' achievement ${ }^{19}$. As stated by Djamarah \& Zain ${ }^{20}$, fun learning is learning designed in such a way so that it gives joyful and exciting atmosphere, and especially which is not dull. In other words, fun learning is the pattern of a good relationship between teachers and learners in the learning process. The active and enjoyable situation is not enough if the learning process is ineffective, which is not to produce what the learners must master after the learning process progresses. Children face learning challenges with foreign language, which in terms of skills such as writing, reading, and pronouncing. This challenges become more difficult when other language uses different letters and writing style ${ }^{21}$. Technology can increase the motivation of teachers to teach creatively as well as a way for students to learn in a fun atmosphere, and improve learning outcomes ${ }^{22}$.

${ }^{16}$ Taufiq Pasiak, Brain Management for Self Improvement (Bandung: Mizan Pustaja, 2007).

17 Susilawati Susilawati, "Penerapan Metoda Bernyanyi Dalam Memingkatkan Kecerdasan Berbahasa Pada Pendidikan Anak Usia Dini (Studi Deskriptif Tentang Penerapan Metoda Bernyanyi Di PAUD Al Azhar Syfa Budi Parahyangan)," EMPOWERMENT : Jurnal Ilmiah Program Studi Pendidikan Luar Sekolah, vol. 3, September 30, (2014), https://doi.org/10.22460/EMPOWERMENT.V3I2P141151.581.

${ }^{18}$ Syahrul Syah Sinaga et al., "Musical Activity in The Music Learning Process Through Children Songs in Primary School Level," Harmonia: Journal of Arts Research and Education 18, no. 1 (2018): 4551, https://doi.org/10.15294/harmonia.v18i1.12508.

19 Darmansyah, Strategi Pembelajaran Menyenangkan Dengan Humor (Jakarta: Bumi Aksara, 2011). 2010).

${ }^{20}$ Syaiful Bahri Djamarah and Aswan Zain, Strategi Belajar Mengajar (Jakarta: Rineka Cipta,

${ }^{21}$ Sameer M. AlNajdi, "Design a Blended Learning Environment to Teach Arabic Alphabet for Non-Arabic Speaker Children Based on ASSURE Model," International Journal of Information and Education Technology 8, no. 2 (2018): 128-32, https://doi.org/10.18178/ijiet.2018.8.2.1021.

22 Rima Chamout, Improving Motivation in Arabic Language Arts Classroom Through Technology Integration (Walden University, 2020). 
In this research, fun learning model is a learning based on song and music. Music can trigger a massive connection in the brain that is responsible for emotion and memory. By using song and music as the tools which maximize human potential is a meaningful effort. Music can be able to motivate and encourage participation in activities that will help to achieve goals in social, language, and motor functions ${ }^{23}$. In line with the statement above, according to the Pasiak ${ }^{24}$, the art, particularly musical songs, is a high nutrient for the brain. Murphey (1992) argues that this is due to the superiority of the human sense of hearing, and according to musical sensibilities, that "music and songs have an appeal that is closer to our language device acquisition rather than spoken language" ${ }^{, 25}$. Zainal Arifin ${ }^{26}$ explained that musical intelligence could be combined with Arabic learning. There are so many aspects of a language that can be delivered and recycled through the use of songs. They can be used at any stage of a lesson and there are many ways to incorporate them into a lesson ${ }^{27}$.

Regarding to the background above, the research questions are divided into three questions, how to use Fun learning approach in Arabic learning, how the impact of using this approach in attracting students to learn Arabic, and how the student's learning outcomes in Arabic subjects after using the approach of fun learning based on a song. Based on research questions, the method that will be used in this research is Classic Experimental Design. The details will be described in the method section. The results of this study are expected to provide an alternative method of learning Arabic for teachers by using fun learning based on music and songs that are attractive to $1^{\text {st }}$ grade students of elementary school.

\section{Method}

The subjects of the research in the Arabic textbook of Muhammadiyah school development were the students in Class $1 \mathrm{~A}$ and $1 \mathrm{~B}$ in the first semester of

${ }^{23}$ Ainoer Roffiq, Ikhwanul Qiram, and Gatot Rubiono, "Media Musik Dan Lagu Pada Proses Pembelajaran," Jurnal Pendidikan Dasar Indonesia 2, no. 2 (2017): 35-40.

${ }^{24}$ Pasiak, Brain Management for Self Improvement.

${ }^{25}$ Yahia Moshtahari, "The Usage of Songs in Arabic as a Foreign Language Classes : Teachers , Perceptions and Practices,”(2018).

${ }_{26}$ Zainal Arifin, "Pengembangan Model Pembelajaran Bahasa Arab Berbasis Teori Multiple Intelligence" Al-Mahara, 1.1 (2015): 1-21.

${ }^{27}$ Nihada Delibegović Džanić and Alisa Pejić, "The Effect of Using Songs On Young Learners and Their Motivation for Learning English," NETSOL: New Trends in Social and Liberal Sciences 1, no. 2 (2016): 40-54, https://doi.org/10.24819/netsol2016.8. 
Muhammadiyah Kadisoka Elementary School, Yogyakarta in the academic year of 2019/2020. The number of students is 29 (average age 6-7 years old) and a teacher. The ratio between male and female students is $14: 15$.

A survey was undertaken to explore the general response of the students to the integration of a fun learning approach in the class. Four statements on the integration of a fun learning approach were given. The students were asked to check a number as a numerical rating scale 5 to 1 (Excellent, Good, Average, Poor, and Very Poor) against the four statements on fun learning based on a song. The second survey is based on the impact of song as a fun learning tool in improving the ability to memorize vocabulary. Eight statements must be responded to by students by checking a number as before.

This research method was Classic Experimental Design: Also known as pretest post-test with control group design. There were at least two groups in this type of research design. One of the two groups serves as a control group. Referring to the above example of classroom performance, section A is the control group. Questionnaires and documentation were used as data collecting. To find out the impact of fun learning in Arabic language teaching class in general and improving the ability to memorize vocabulary (Mufradhat) at $1^{\text {st }}$ grade of Muhammadiyah Kadisoka Elementary School in Yogyakarta, two types of the statistical survey were conducted.

The next step was the test. This test was based on pretest and post-test. Pre-test was conducted before the use of a fun learning approach. Fifty-eight students from 2 classes were asked to answer ten multiple-choice questions about vocabulary. Their answers were noted down. The week after, 29 students in the experimental group were given lessons using a textbook based on song, and another 29 students in the control group were not. At this point, the students were given the post-test according to the theme of the lesson being given. This test aimed to find out how a textbook based on song as one of the fun learning tools helps students improving their ability to memorize vocabulary. To collect data on students' pre-test and post-test scores, documentation was used.

The descriptive analysis was used as technique of data analysis. According to Hendrawati \& Prasojo ${ }^{28}$, this analysis showed the number of subjects in the group, the

${ }^{28}$ Anik Hendrawati and Lantip Diat Prasojo, "Pengaruh Kepemimpinan Transformasional Kepala Sekolah, Motivasi Kerja Guru, Dan Budaya Sekolah Terhadap Prestasi Belajar," Jurnal Akuntabilitas Manajemen Pendidikan 3, no. 2 (October 26, 2015): 141-57, https://doi.org/10.21831/amp.v3i2.6331. 
mean of the tests scores, standard deviation of tests scores, maximum scores, minimum scores, and histograms.

\section{Result and Discussion}

\section{The Observasions, Interviews, and Assesments}

This research was conducted by using the observation and interviews method for the Arabic teacher and the students of $1^{\text {st }}$ grade in Muhammadiyah Kadisoka Elementary School from November 20 to 27, 2019. From preliminary observations, the following results were found as follows: (1) The teaching method used by the teacher is manual memorization method and students are asked to repeat after the teacher. (2) The ability to read Hijaiyah letters for $1^{\text {st }}$ grade students is still poor, from 38 students, only 5 students can read Holy Quran, 10 other students have just studied the Iqra' book volume 5 and the rest are in volumes 1 and 2. (3) The observation of the student's result recapitulations, there were 13 students who did not pass the minimum competency standard achievement indicator with $K K M$ (criteria of minimum achievement) score which was 75 . This data showed that in terms of learning outcomes, it has not shown a good results.

In addition to observation, researchers also conducted interviews with Arabic language teachers and students on October 5 to 10, 2019. The conclusions of the interview are as follows: (1) Generally, in the Arabic learning process, a traditional listening method was still used; the teacher reads the material vocabulary words and the students repeat what the teacher says. (2) There are no Arabic textbooks for $1^{\text {st }}$ grade from Primary and Secondary Education Institutions of Muhammadiyah Central Leadership which has made the difficulties for the learning process in Muhammadiyah Kadisoka Elementary School. It has organized an Arabic learning curriculum from the beginning. (3) During the Arabic learning process, teachers rarely use learning media. So far, Arabic dictionary books and children's writing books are the only media to support the learning process. (4) The approach used by the teacher is a teacher-centered so that students become passive and bored in the learning process. (5) Students are not encouraged to be active during the learning process. Hence, the students do not pay attention to the teacher so that learning outcomes are not optimal in the end. (6) Students' learning outcomes tend to decrease and there are still many students who have not exceeded the minimum competency achievement standard. It was recorded from the 
results of class $1 \mathrm{~A}$ tests about number of Hijaiyah, there were 13 students who had not mastered it. (7) Teachers frequently face problems of correcting students' test answers due to tight teaching schedules, so that the results of student tests cannot be immediately known. (8) The teacher does not evaluate textbooks that have been used before, so it is not known the effectiveness level of using textbooks in the Arabic learning process. (9) The teacher finds difficulties in the learning process because the textbook used does not present question exercises so that the teacher must create and formulate each students' understanding exercises by themselves

Based on the results of observations and interviews conducted by researchers with students and teachers above, the following points were concluded: (1) More than $50 \%$ of $1^{\text {st }}$ grade students are able to read and write simple Arabic writing so that it is very supportive of the development of textbooks based on song. (2) Teachers really hope that teaching materials in the textbooks for Arabic learning are interesting and fun and can be used in learning. So that the textbook can make it easier for students to follow the learning process. (3) Teachers strongly support textbooks based on song which contains material and competency test exercises and different songs are available in each chapter. (4) The school principal motivates the creativity of teachers in creating learning innovations. This is proven by the existence of various training programs for making learning media for teachers. (5) The school principal concerns to the instructional materials used by teachers in managing the learning process in the classroom.

The survey and observations results above are the starting point for researchers to develop Arabic teaching materials into a product that can be tested on students. The trials of textbooks based on the song are conducted through an experiment in the control class and experimental class. The control class did not use the Arabic textbook based on songs in the learning process. In contrast, the experimental class used an Arabic textbook based on songs in the learning process from the beginning until the end of experiments. In this step, the researchers used pretest and post-test for both classes which were control class and experimental class, in which the wide-scale trials were conducted on Tuesday, October 28, 2019, until Friday, November 1, 2019. The place of the research was Muhammadiyah Kadisoka Elementary School in Yogyakarta.

Multiple choice questions were used in both classes; control class and experimental class. The first pretest was given to 29 participants of $1^{\text {st }}$ grade using the questions read by the researchers, and then the students answered the questions in their 
answer sheet. The second was experimental class, which is treated by giving a post-test to 29 students of class 1B who are invited to sing the materials based on songs developed by the researchers. Then the researchers read the questions to be answered in the students' answer sheet.

\section{Learning Outcome in Control Class}

In the learning process, the teachers prepared the lesson plan (RPP) with part of the body as the subject material. In this lesson plan, the learning activity was conducted in 2 hours without using textbook based on song as the media of the material teaching. This step was followed by 29 students of $1 \mathrm{~B}$.

Table 1. Pretest and Post-test Outcome of The Control Class

\begin{tabular}{cccc}
\hline No & Score & Total of Stidents in Prestest & Total of Stidents in Post-test \\
\hline 1 & 30 & 2 & - \\
2 & 40 & - & - \\
3 & 50 & 6 & 1 \\
4 & 60 & 11 & 6 \\
5 & 70 & 9 & 14 \\
6 & 80 & 1 & 8 \\
\hline
\end{tabular}

From the table 1, it can be seen in the Control Class that the lowest score during the pretest was 30, and the lowest score during the post test rose to 50. The highest score (80) previously was only obtained by 1 student, when the post-test increased to 8 students. Although it shows an increase, the increase is less significant.

\section{Learning Outcome in Experimental Class}

In the learning process in the experimental class, the teachers prepared the lesson plan (RPP), it is the same lesson plan in the control class. In the lesson plan, learning activity was conducted in one hour and used textbook based on songs as the media of the teaching material. This activity was followed by 29 students in class 1A, in which the questions provided consisted of 10 multiple-choice questions. The result in the experimental class is in the table below:

Table 2. The Pretest and Post-Test Outcome of the Experimental Class

\begin{tabular}{cccc}
\hline No & Score & Total of Stidents in Prestest & Total of Stidents in Post-test \\
\hline 1 & 30 & 1 & - \\
2 & 40 & 1 & - \\
3 & 50 & 6 & - \\
4 & 60 & 12 & - \\
5 & 70 & 9 & 2 \\
6 & 80 & - & 11 \\
7 & 90 & - & 11 \\
\hline
\end{tabular}




\begin{tabular}{llll}
\hline 8 & 100 & - & 5 \\
\hline
\end{tabular}

From the table 2, it can be seen that there is a significant increase in student test results in the Experimental Class during pretest and post-test. The lowest pretest score was 30 and rose significantly to 70 at the post-test. And the previous highest score was 70 , then it rose significantly to 100 and was obtained by 5 students.

\section{The Analysis of Control Class and Experimental Class}

Table 3. Final Report of Control and Experimental Class Score

\begin{tabular}{lcc}
\hline \multicolumn{1}{c}{ Information } & \multicolumn{2}{c}{ Ability } \\
\cline { 2 - 3 } & Before & After \\
\hline Average score in the control class & 59,7 & 70 \\
Average score in the experimental class & 59,3 & 86,6 \\
The highest score in the control class & 70 & 80 \\
The highest score in the experimental class & 80 & 100 \\
The lowest score in the control class & 30 & 50 \\
The lowest score in experimental class & 30 & 70 \\
\hline
\end{tabular}

The table 3 is a recapitulation of the final results obtained by students in the Control Class and Experimental Class. From the table above, it can be seen the difference between the Control Class and the Experimental Class during the pretest and post-test.

\section{The Effectiveness and Importance of Using "Arabic Textbook based on Song"}

Based on table 2 above, it shows that there is the significant improvement of learning outcome. It is proven by the ratio before and after treatment by using Arabic textbooks based on songs. Before and after using the media gained an increase in the average 86.6. Therefore, it can be concluded that the use of "Arabic textbook based on song" can increase students' learning outcomes. Not only the score ratio increase significantly, the use of this Arabic textbooks based on songs also can save the time of study, in the control class it took two hours to provide material while in the experimental class it only took one hour.

According to Davis ${ }^{29}$, songs have been a common feature of young learner classrooms for decades and should be employed in order to improve motivation and facilitate the acquisition of various aspects of language, including vocabulary, grammar, pronunciation, and listening skills. It proved that the use of songs in foreign languages

${ }^{29}$ Davis, G, 'Songs in the Young Learner Classroom: A Critical Review of Evidence', ELT Journal, 71.4 (2017): 445-455 <https://doi.org/10.1093/elt/ccw097>. 
learning for elementary school students is very significant, as has been proven in this study. Other studies have also proven the effectiveness of using songs in foreign language learning in elementary schools in Indonesia ${ }^{30}$. Using songs in teaching foreign language, especially Arabic in this case, can eleminate burden of learning and give students joy to improve understanding of various aspects of language they have learned. Based on the explanation above, the purpose of using songs in learning is to minimize students' boredom in the learning process and make students easier to understand the material, so they can get the satisfying results.

The use of song related to children's phonetic language skills starting around the age of 5. Music and foreign language learning capacity can be related to each other. Moreover, these findings emphasize that the possibility of children's early childhood developed abilities may be responsible for the linguistic and musical performance in every individual $^{31}$.

The most difficult aspect of language learning is to acquire the vocabulary. Therefore, acquiring vocabulary as fast as possible is seen as a very important thing in language learning. According to its use, Haycraft ${ }^{32}$ classified vocabulary into two types; (1) active vocabulary, and (2) passive vocabulary. Active vocabulary is used in speaking and writing (productive skills) and passive vocabulary is used when listening and reading (receptive skills). In this research, studying Arabic vocabulary at $1^{\text {st }}$ grade of elementary school aims to start learning Arabic. It is hoped that by acquiring a lot of vocabulary, students will learn other aspects of the Arabic easily.

Thus, $1^{\text {st }}$ grade elementary school teachers should provide teaching materials. A material itself was made as Arabic textbook based on songs. The steps must be done before using the product are first validation, product revision, second validation, and final product. After that, before using the product, the researchers collected the data, and further was conducted the effectiveness test of learning material developed in Arabic learning. Furthermore, the researchers conducted a trustworthiness test of learning media that can be seen from the difference that appeared before and after using the media to 29

\footnotetext{
${ }^{30}$ Kurniati et al., "The Effectiveness of Audio Media for English Learning Based on Scripted Song at the Fifth Grade of Elementary School.” Ilkögretim Online, 20.1 (2021): 208-16.

${ }^{31}$ Christiner and Reiterer, "Early Influence of Musical Abilities and Working Memory on Speech Imitation Abilities: Study with Pre-School Children." Brain Sciences, 8.9 (2018): 1-16 <https://doi.org/10.3390/brainsci8090169>
} 
students of the first grade of Muhammadiyah Kadisoka Elementary School. The assessment results were obtained from pretest and post-test scores. Those are based on data obtained from the differences of both data.

From the differences of both data, it is then carried out the hypothesis tests to determine the effectiveness of teaching materials developed by researchers. Examining the effectiveness test, the researchers used a paired T-test formula that is processed using SPSS 23.0 - starting with the normality test to examine the "difference" data normality (pre-post value). There were two choices used to examine the normality test; Kolmogorov-Smirnov or Shapiro-Wilk. Because the sample is small $(<30)$, the normality test used to examine was Shapiro-Wilk ${ }^{33}$. The results obtained from the test are presented below:

Table 4. Case Processing Summary

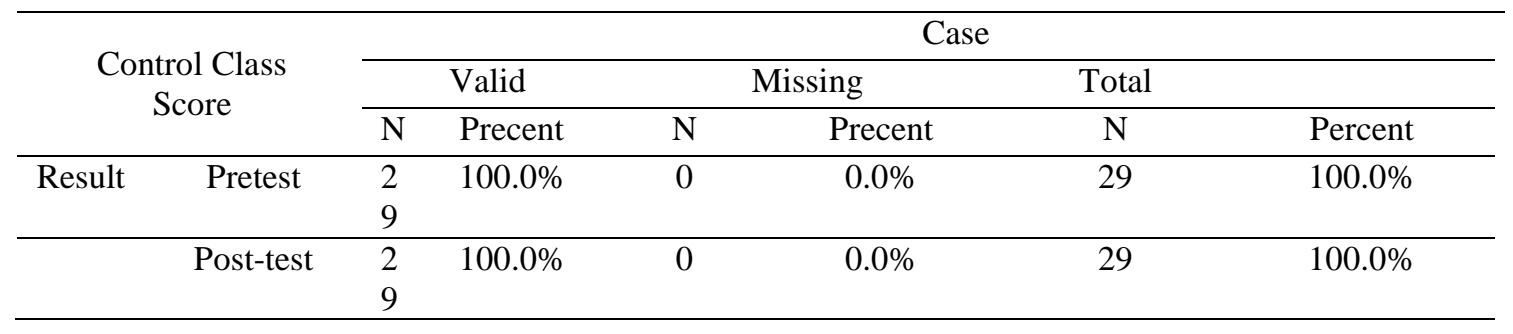

Table 5. Descriptives

\begin{tabular}{lllll}
\hline Descriptives & & & \\
\hline \multicolumn{2}{c}{ Control class } & Statistic & Std. Error \\
\hline Result & Pretest & Mean & 59.6552 & 2.13364 \\
\cline { 2 - 4 } & $95 \%$ Confidence Interval for & Lower Bound & 55.2846 & \\
& Mean & Upper Bound & 64.0257 & \\
& 5\% Trimmed Mean & 60.3448 & \\
& Median & 60.0000 & \\
& Variance & 132.020 & \\
& Std. Deviation & 11.48998 & \\
& Minimum & 30.00 & \\
Maximum & 80.00 & .434 \\
& Range & 50.00 &
\end{tabular}

\footnotetext{
1994).

${ }^{32}$ John Haycraft, An Introduction to English Language Teaching (Singapore: Longman Group Ltd.,

${ }^{33}$ Purbayu Budi Santosa, Analisis Statistik Dengan Microsoft Excel Dan SPSS (Yogyakarta: Penerbit Andi, 2005).
} 
The Effectiveness of .... | Betty Mauli Rosa Bustam, Iswanto, Mhd. Lailan Arqam, Wikanti Iffah Juliani, Akhmad Najibul Khairi

\begin{tabular}{llll}
\hline \multirow{2}{*}{ Post-test } & Kurtosis & 1.407 & .845 \\
& Mean & 70.0000 & 1.48888 \\
95\% Confidence Interval for & Lower Bound & 66.9502 & \\
Mean & Upper Bound & 73.0498 & \\
5\% Trimmed Mean & 70.3831 & \\
Median & 70.0000 & \\
Variance & 64.286 & \\
Std. Deviation & 8.01784 & \\
Minimum & 50.00 & \\
Maximum & 80.00 & \\
Range & 30.00 & \\
Interquartile Range & 15.00 & \\
Skewness & -.447 & .434 \\
Kurtosis & -.137 & .845 \\
\hline
\end{tabular}

Table 6. Case Processing Summary

\begin{tabular}{|c|c|c|c|c|c|c|c|}
\hline & \multirow[b]{3}{*}{ Experimental class } & \multicolumn{6}{|c|}{ Cases } \\
\hline & & \multicolumn{2}{|l|}{ Valid } & \multicolumn{2}{|l|}{ Missing } & \multicolumn{2}{|c|}{ Total } \\
\hline & & $\overline{\mathrm{N}}$ & Percent & $\mathrm{N}$ & Percent & $\mathrm{N}$ & Percent \\
\hline \multirow[t]{2}{*}{ Result } & Pretest & 29 & $100.0 \%$ & 0 & $0.0 \%$ & 29 & $100.0 \%$ \\
\hline & Post-test & 29 & $100.0 \%$ & 0 & $0.0 \%$ & 29 & $100.0 \%$ \\
\hline
\end{tabular}

Table 7. Descriptives

\begin{tabular}{lllll}
\hline \multicolumn{2}{l}{ Experimental class } & Statistic & Std. Error \\
\hline Result & Pretest & Mean & 59.3103 & 1.85237 \\
& $95 \%$ Confidence Interval for & Lower Bound & 55.5159 & \\
& Mean & Upper Bound & 63.1048 & \\
& 5\% Trimmed Mean & 60.1724 & \\
& Median & 60.0000 & \\
& Variance & 99.507 & \\
Std. Deviation & 9.97534 & \\
& Minimum & 30.00 & \\
& Maximum & 70.00 & \\
& Range & 40.00 & \\
& Interquartile Range & 20.00 & \\
& Skewness & -1.014 & .434 \\
& Kurtosis & 1.297 & .845 \\
& Mean & 86.5517 & 1.59091
\end{tabular}




\begin{tabular}{lll} 
95\% Confidence Interval for & Lower Bound & 83.2929 \\
Mean & Upper Bound & 89.8106 \\
5\% Trimmed Mean & 86.7241 & \\
Median & 90.0000 & \\
Variance & 73.399 & \\
Std. Deviation & 8.56732 & \\
Minimum & 70.00 & \\
Maximum & 100.00 & \\
Range & 30.00 & \\
Interquartile Range & 10.00 & .434 \\
Skewness & .027 & .845 \\
Kurtosis & -.594 & \\
\hline
\end{tabular}

Three indicators that are reviewed from the aspect of product efficiency are the efficiency of time in learning, the materials, and the media to support the learning activity. All of those were obtained by the teacher that "Arabic Textbook based on song" was able to assist the learning process. The result was evidenced by the interview results.

This study showed that the Arabic textbook based on song for teaching materials are able to improve the ability of students from the cognitive aspect or the ability to think, this is in line with the opinion of Kuswana ${ }^{34}$ which stated that one of the conditions that students are considered successful in learning if there is a change for a better aspect; cognitive and affective or psychomotor. In this case, the teaching material in the form of developed textbooks was declared successful in improving the cognitive abilities of students, as evidenced by the learning outcomes of children in Arabic subjects about "part of body" increased significantly.

In terms of psychomotor or skills, Arabic textbook teaching materials developed are also able to improve student learning skills in terms of communication and expression. This is in line with the results of Susilawati's ${ }^{35}$ research which stated that learning by using song or singing can improve children's skills in communication and interaction.

${ }^{34}$ W. S. Kuswana, Taksonomi Kognitif Perkembangan Ragam Berpikir (Bandung: Rosda Karya, 2014).

${ }^{35}$ Susilawati, "Penerapan Metoda Bernyanyi Dalam Memingkatkan Kecerdasan Berbahasa Pada Pendidikan Anak Usia Dini (Studi Deskriptif Tentang Penerapan Metoda Bernyanyi Di PAUD Al Azhar Syfa Budi Parahyangan)." EMPOWERMENT : Jurnal Ilmiah Program Studi Pendidikan Luar Sekolah, 30 September 2014: 141-151 <https://doi.org/10.22460/EMPOWERMENT.V3I2P141-151.581> 
In addition, from the explanation above, teaching materials with Arabic language books based on songs can also help to develop musical intelligence in students because in every lesson, teachers and students are presented with vocabulary material in the form of songs. This is in line with the opinion of $\operatorname{Arifin}^{36}$ which stated that to improve the musical intelligence, singing in the learning process can be the method of learning.

\section{Conclusion}

The results of this study showed that fun learning based on song textbook in Arabic learning was in accordance with the needs of $1^{\text {st }}$ grade students at Muhammadiyah Kadisoka Elementary School in Yogyakarta. This is indicated by the improvement of their understanding about the Arabic material taught by the teacher by using music and songs, accompanied by an improvement in their test scores evenly, there is no plummeting grades after receiving the music and songs material from the teacher. Due to COVID-19 outbreak, face-to-face or offline meetings in the classrooms conventionally are not available. It makes this research even more significant. Students who study online at home need a fun learning activity that keep them excited about studying the various materials, even though they do not get the guidance from the teachers directly. The weakness of this research is the possibility that not all Arabic teachers know all of the songs that have been selected by the researchers in the textbook. This is due to the lack of children's songs nowadays that can be used. In the future, hopefully Arabic teachers can make better innovations by utilizing more songs that are familiar for the students so that this Arabic textbook is more diverse and complete. Hopefully, this research can be useful for the sustainability of teaching and online learning activities and can provide maximum results for all students in Arabic learning.

\section{Acknowledgment}

Researchers would like to thank the Principal and the Arabic teachers at Muhammadiyah Kadisoka Elementary School in Yogyakarta, who have supported and assisted in providing the data and information to achieve the objectives of this study. Thanks to LPPM (Institute of Research and Community Service) Universitas Ahmad Dahlan for providing the facilities in the implementation of this research.

${ }^{36}$ Arifin, "Pengembangan Model Pembelajaran Bahasa Arab Berbasis Teori Multiple Intelligence." 301 | Jurnal Al Bayan: Jurnal Jurusan Pendidikan Bahasa Arab, 13 (2): 286-304 (2021) 


\section{References}

Al-Bulushi, Ali H., and Ali S. Al-Issa. "Playing with the Language: Investigating the Role of Communicative Games in an Arab Language Teaching System." International Journal of Instruction 10, no. 2 (2017): 179-98. https://doi.org/10.12973/iji.2017.10212a.

Al-Jarf, Reima S., and Nailya G. Mingazova. "Evaluation of Arabic Language Teaching Textbooks Used in Russia in the Light of the CEFR Criteria." In VI International Forum on Teacher Education, 1:101-29, 2020. https://doi.org/10.3897/ap.2.e0101.

Al-Khresheh, Mohammad H., Ahmad Khaerurrozikin, and Abdul Hafidz Zaid. "The Efficiency of Using Pictures in Teaching Speaking Skills of Non-Native Arabic Beginner Students." Universal Journal of Educational Research 8, no. 3 (2020): 872-78. https://doi.org/10.13189/ujer.2020.080318.

AlNajdi, Sameer M. "Design a Blended Learning Environment to Teach Arabic Alphabet for Non-Arabic Speaker Children Based on ASSURE Model." International Journal of Information and Education Technology 8, no. 2 (2018): 128-32. https://doi.org/10.18178/ijiet.2018.8.2.1021.

Arifin, Zainal. "Pengembangan Model Pembelajaran Bahasa Arab Berbasis Teori Multiple Intelligence" 1, no. 1 (2015).

Arwani, Agus. "The Role of The Arabic Language in Islamic Economy." Alsinatuna 3, no. 1 (2013): 97-112.

Boudelaa, Sami, and William D. Marslen-Wilson. "Morphological Structure in the Arabic Mental Lexicon: Parallels between Standard and Dialectal Arabic." Language and Cognitive Processes 28, no. 10 (December 2013): 1453-73. https://doi.org/10.1080/01690965.2012.719629.

Cahaya, Meta. "Penerapan Model Pembelajaran Inkuiri Untuk Meningkatkan Motivasi Belajar PPKn Siswa Di Kelas VII C SMP Negeri 7 Muaro Jambi,” July 23, 2020.

Chamout, Rima. "Improving Motivation in Arabic Language Arts Classroom Through Technology Integration.” Walden University, 2020.

Christiner, Markus, and Susanne Maria Reiterer. "Early Influence of Musical Abilities and Working Memory on Speech Imitation Abilities: Study with Pre-School Children.” Brain Sciences 8, no. 9 (2018). https://doi.org/10.3390/brainsci8090169.

Darmansyah. Strategi Pembelajaran Menyenangkan Dengan Humor. Jakarta: Bumi Aksara, 2011.

Davis, G. "Songs in the Young Learner Classroom: A Critical Review of Evidence." ELT Journal 71, no. 4 (2017). https://doi.org/10.1093/elt/ccw097.

Djamarah, Syaiful Bahri, and Aswan Zain. Strategi Belajar Mengajar. Jakarta: Rineka 
Cipta, 2010.

Džanić, Nihada Delibegović, and Alisa Pejić. "The Effect of Using Songs On Young Learners and Their Motivation for Learning English." NETSOL: New Trends in Social and Liberal Sciences 1, no. 2 (2016): 40-54. https://doi.org/10.24819/netsol2016.8.

"Fun Learning Approach - Nurturing A Passion For Learning • Fun Academy." Accessed September 21, 2020. https://funacademy.fi/fun-learning-approach/.

Haycraft, John. An Introduction to English Language Teaching. Singapore: Longman Group Ltd., 1994.

Hendrawati, Anik, and Lantip Diat Prasojo. "Pengaruh Kepemimpinan Transformasional Kepala Sekolah, Motivasi Kerja Guru, Dan Budaya Sekolah Terhadap Prestasi Belajar." Jurnal Akuntabilitas Manajemen Pendidikan 3, no. 2 (October 26, 2015): 141-57. https://doi.org/10.21831/amp.v3i2.6331.

Kurniati, Erisa, Muhammad Zaim, Jufrizal, and Jufri. "The Effectiveness of Audio Media for English Learning Based on Scripted Song at the Fifth Grade of Elementary School." Illkögretim Online 20, no. 1 (2021): 208-16. https://doi.org/10.17051/ilkonline.2021.01.023.

Kuswana, W. S. Taksonomi Kognitif Perkembangan Ragam Berpikir. Bandung: Rosda Karya, 2014.

Masrai, Ahmed, and James Milton. "Recognition Vocabulary Knowledge and Intelligence as Predictors of Academic Achievement in EFL Context." TESOL International Journal 12, no. 1 (2017): 128-42.

Moshtahari, Yahia. "The Usage of Songs in Arabic as a Foreign Language Classes : Teachers' Perceptions and Practices," 2018.

Pasiak, Taufiq. Brain Management for Self Improvement. Bandung: Mizan Pustaja, 2007.

Roffiq, Ainoer, Ikhwanul Qiram, and Gatot Rubiono. "Media Musik Dan Lagu Pada Proses Pembelajaran.” Jurnal Pendidikan Dasar Indonesia 2, no. 2 (2017): 35-40.

Santosa, Purbayu Budi. Analisis Statistik Dengan Microsoft Excel Dan SPSS. Yogyakarta: Penerbit Andi, 2005.

Sinaga, Syahrul Syah, Susanto Susanto, Victor Ganap, and Tjetjep Rehendi Rohidi. "Musical Activity in The Music Learning Process Through Children Songs in Primary School Level." Harmonia: Journal of Arts Research and Education 18, no. 1 (2018): 45-51. https://doi.org/10.15294/harmonia.v18i1.12508.

Somjai, Satit, and Kittitouch Soontornwipast. "The Integration of Implicit and Explicit Vocabulary Instruction, Project-Based Learning, Multimedia, and Experiental Learning to Improve Thai EFL Senior High School Students' Vocabulary Ability." Arab World English Journal 6, no. Special (2020): 171-90. 
https://doi.org/https://dx.doi.org/10.24093/awej/call6.12.

Susilawati, Susilawati. "Penerapan Metoda Bernyanyi Dalam Memingkatkan Kecerdasan Berbahasa Pada Pendidikan Anak Usia Dini (Studi Deskriptif Tentang Penerapan Metoda Bernyanyi Di PAUD Al Azhar Syfa Budi Parahyangan)." EMPOWERMENT: Jurnal Ilmiah Program Studi Pendidikan Luar Sekolah. Vol. 3, September 30, 2014. https://doi.org/10.22460/EMPOWERMENT.V3I2P141151.581.

Wekke, Ismail Suardi. "Arabic Teaching and Learning: A Model From Indonesian Muslim Minority.” Procedia-Social and Behavioral Sciences 191, 2015, 286-90. 